\title{
Содержание хлоридных ионов в воде реки Волга
}

\author{
В.А. Селезнев ${ }^{凶}$ А. В. Селезнева \\ Самарский федеральный исследовательский иентр Российской академии наук, \\ Институт экологии Волжсккого бассейна РАН, Российская Федераџия \\ (445003, Самарская обл., г. Тольятти, ул. Комзина, 10)
}

\begin{abstract}
Аннотация: Цель исследований - определение закономерностей сезонной изменчивости содержания хлоридных ионов в воде реки Волга и количественная оценка амплитуды межгодовых и внутригодовых изменений с учетом лет разной водности.

Материальь и методы. В период 2001-2018 годов на реке Волга проводились систематические гидрохимические наблюдения. Стационарный пункт наблюдений расположен на левом берегу реки, на расстоянии 2,5 км ниже по течению от створа Жигулевского гидроузла (замыкающий створ Куйбышевского водохранилища). Пробы воды отбирались с бетонной стенки батометром Молчанов ГР-18 с поверхностного горизонта. Количество отобранных проб составляет 216. Массовая концентрация хлоридных ионов $\left(\mathrm{Cl}^{-}\right)$определялась в соответствии с действующими руководящими документами Росгидромета. Статистический анализ данных о расходах воды и концентрации хлоридных ионов осуществлялся в программной среде Statistica.

Результаты и обсуждение. Средняя концентрация хлоридных ионов за 18-летний период наблюдений составила $27,0 \pm 2,2$ мг/дм³. Наибольшая средняя годовая концентрация хлоридов достигла $31,0 \pm 2,3$ мг/дм³ , а наименьшая - 24,2 $\pm 2,1$ мг/дм³. Содержание хлоридов характеризовалось хорошо выраженной сезонной изменчивостью. В период зимней межени происходило постепенное увеличение концентрации хлоридов. Максимум наблюдался в апреле, перед началом весеннего половодья. В период весеннего половодья концентрация хлоридов резко уменьшалась, достигая наименьших значений в мае в пик весеннего половодья. В летний период концентрация их постепенно увеличивалась, а в осенний период - уменьшалась. Сезонная амплитуда концентраций хлоридов изменялась от 14,0 $\pm 1,8$ мг/дм до $41,3 \pm 2,6$ мг/дм³. В годы различной водности амплитуда сезонных колебаний может увеличиваться или уменьшаться. В периоды весеннего половодья многоводных лет концентрация хлоридов резко снижалась, а в меженные периоды маловодных лет - существенно увеличивалась. В целом, в многоводные годы концентрация хлоридов уменьшалась, а маловодные - увеличивалась из-за смены соотношения поверхностной и подземной составляющих формирования водного стока.

Bblвoдbl. При оценке качества воды и определении пространственной неоднородности концентрации хлоридных ионов необходимо учитывать закономерности их сезонной изменчивости.
\end{abstract}

Ключевые слова: река Волга, створ Жигулевского гидроузла, хлоридные ионы, сезонная изменчивость, влияние водности.

Для цитирования: Селезнев В. А., Селезнева А. В. Содержание хлоридных ионов в воде реки Волга // Вестник Воронежского государственного университета. Серия: География, Геоэкология, 2021, № 4, c. 34-41. DOI: https://doi.org/10.17308/geo.2021.4/3748

\section{ВВЕДЕНИЕ}

Хлоридные ионы относятся к главным ионам химического состава природных вод. В поверхностных водах хлориды распространены повсеместно, а их содержание изменяется в широких пределах от 1 до 1000 мг/дм ${ }^{3}$ в зависимости от природно-климатиче-

(C) Селезнев В.А., Селезнева А. В., 2021

$\triangle$ Селезнев Владимир Анатольевич, e-mail: seleznev53@mail.ru ских условий [6]. Первичными источниками хлоридов в поверхностных водах являются магматические породы, в состав которых входят хлорсодержащие минералы (содалит, хлорапатит и др.), соленосные отложения, в основном галит. Значительные количества хлоридов поступают в водные объекты из различных природных сред - с акватории океанов через 
атмосферу; в результате взаимодействия атмосферных осадков с почвами, особенно засоленными; при вулканических выбросах. Часть хлоридов сбрасывается в водные объекты со сточными водами, а часть поступает от диффузных источников загрязнения, расположенных на водосборной территории. Хлориды обладают рядом особенностей - большой миграционной способностью, что объясняется их хорошей растворимостью; слабовыраженной способностью к сорбции на взвешенных веществах и к потреблению водными организмами [3].

Содержание хлоридов в воде оказывает воздействие на состояние водных экосистем, органолептические свойства воды и организм человека. Повышенное содержание хлоридов ухудшает вкусовые качества воды, которая становится малопригодной для питьевого водоснабжения, что ограничивает её применение для многих технических и хозяйственных целей, в том числе для орошения. Предельно допустимая концентрация (ПДК) хлоридов для водных объектов рыбо-хозяйственного назначения составляет $300 \mathrm{мг} /$ дм³ $^{3}$, для хозяйственно-питьевого водоснабжения - $350 \mathrm{мг} /$ дм³ $^{3}$. При поливе растений концентрация хлоридов должна находиться на уровне 50-300 мг/дм³ в зависимости от вида растения.

В волжской воде основное внимание при изучении содержания хлоридов уделялось оценке их пространственной неоднородности по длине русла реки $[4,5,8,13]$. Закономерности сезонной изменчивости хлоридов и межгодовые колебания оценивались фрагментарно [10]. Поэтому цель исследования - дать количественную оценку сезонной изменчивости хлоридов на основе данных систематических многолетних наблюдений, полученных на реке Волга в створе Жигулевского гидроузла. В условиях высокой антропогенной нагрузки [3, 9] и глобального потепления климата [1] актуальность подобных исследований возрастает.

\section{МАТЕРИАЛЫ И МЕТОДЫ}

Гидрохимические наблюдения нами проводились систематически в период 2001-2018 годов в районе Жигулевского гидроузла $[2,11,14]$. Через данный створ проходит практически весь водный сток реки Волги. Жигулевский гидроузел - выходной створ Куйбышевского водохранилища (рис. 1). Входными створами для него по волжской ветке относится Чебоксарский гидроузел, а по камской ветке - Нижнекамский гидроузел. Ниже по течению от Жигулевского гидроузла расположены Саратовское и Волгоградское водохранилища.

Основное сезонное регулирование водного стока реки осуществляется на Куйбышевском водохранилище, и проводит его эксплуатирующая организация - Филиал ОАО «РусГидро» - «Жигулевская ГЭС» в соответствии с «Основными правилами использования водных ресурсов Куйбышевского

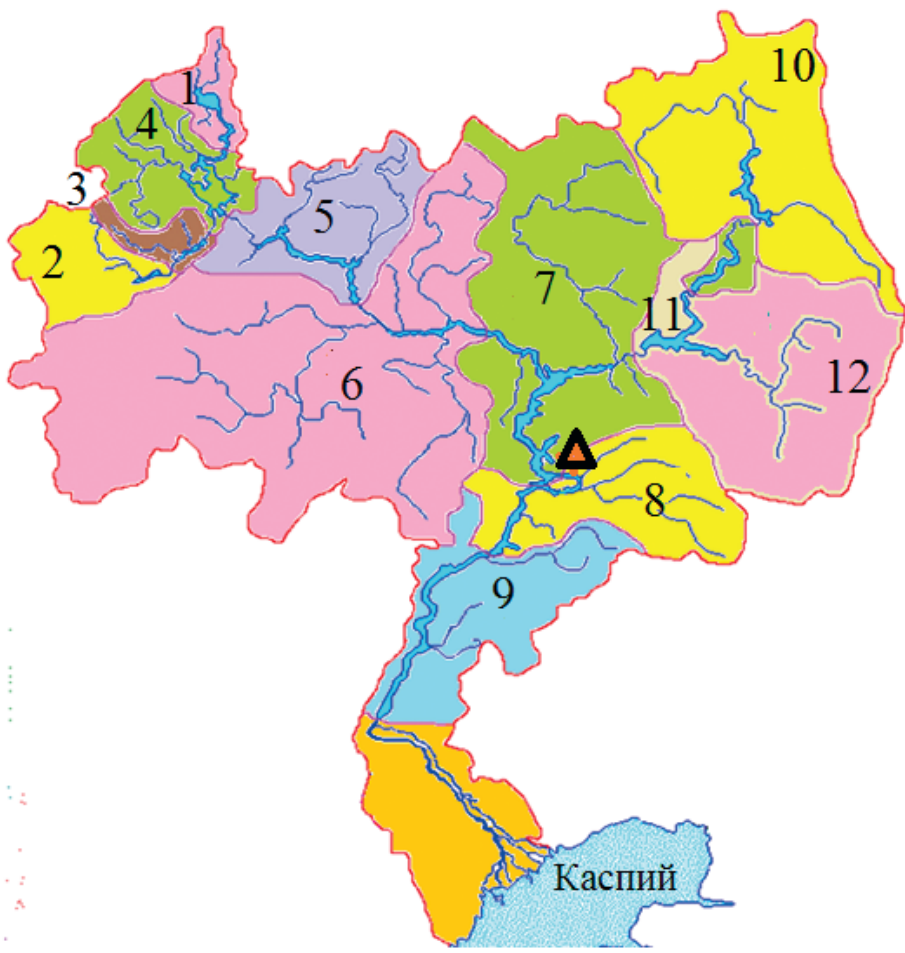

Бассейны водохранилищ:

Шекснинское (1),

Угличское (2),

Иваньковское (3),

Рыбинское (4),

Горьковское (5),

Чебоксарское (6),

Куйбышевское (7),

Саратовское (8),

Волгоградское (9)

Камское (10),

Воткинское (11),

Нижнекамское (12).

Puc. 1. Расположение пункта наблюдений $(\Delta)$ в бассейне реки Волга

[Fig. 1. Observation point location $(\Delta)$ in the Volga river basin]

Вестник ВГУ, Серия: География. Геоэкология, 2021, № 4, 34-41 
водохранилища на р. Волге», утвержденными приказом Министерства мелиорации и водного хозяйства РСФСР от 11 ноября 1983 г. № 596.

Длина Куйбышевского водохранилища по волжскому направлению составляет 510 км, а по камскому - 240 км. Максимальная ширина - 40 км, максимальная глубина $-40,0$ м. Общий объем водохранилища равен 57,3 км³ , а полезный - 30,7 км³. Средний многолетний водный сток составляет 244 км$^{3}$, максимальный - 366 км $^{3}$, минималь-

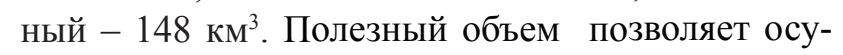
ществлять сезонное, недельное и суточное регулирование водного стока в интересах различных водопользователей. Для многолетнего регулирования водного стока емкость Куйбышевского водохранилища недостаточна.

Пункт гидрохимических наблюдений расположен на левом берегу Саратовского водохрани- лища в 2,5 км ниже по течению от Жигулевского гидроузла. В состав гидроузла входят: гидроэлектростанция, совмещённая с донными водосбросами; бетонная водосливная плотина; двухступенчатый шлюз. Ширина водохранилища в пункте наблюдения составляет 1,0 км, а глубина 6 м.

Отбор проб воды осуществлялся батометром Молчанова ГР-18 с поверхностного горизонта с причальной бетонной стенки в соответствии с нормативными требованиями (ГОСТ Р 515922000). Пробы воды фильтровали через мембранный фильтр 0,45 мкм, промытый дистиллированной водой. Пробы воды в течение одного часа автотранспортом доставлялись в испытательную лабораторию. Определение массовой концентрации хлоридных ионов $\left(\mathrm{Cl}^{-}\right)$выполнялось в соответствии с руководящими документами Росгидромета (табл. 1).

Таблица 1

Диапазон и точность измерения массовой концентрации хлоридных ионов $\left(\mathrm{Cl}^{-}\right)$

[Table 1. Range and accuracy of measurement of mass concentration of chloride ions $\left(\mathrm{Cl}^{-}\right)$]

\begin{tabular}{|c|c|c|}
\hline $\begin{array}{c}\text { Методика анализа / } \\
\text { Analysis method }\end{array}$ & $\begin{array}{c}\text { Диапазон измерений массовой } \\
\text { концентрации } \mathrm{Cl}^{-} \\
\text {мг/дм³ } \\
\text { Range of measurement of mass } \\
\text { concentration } \mathrm{Cl}^{-}, \mathrm{mg} / \mathrm{dm}^{3}\end{array}$ & $\begin{array}{c}\text { Показатель точности } \\
\text { (границы погрешности при } \\
\text { вероятности } \mathrm{P}=0,95) \\
\pm \Delta, \mathrm{Mг} / \text { дм }^{3} / \\
\text { Accuracy index } \\
\text { (error limits at probability } \mathrm{P}=0,95 \text { ) } \\
\pm \Delta, \mathrm{mg} / \mathrm{dm}^{3} \\
\end{array}$ \\
\hline $\begin{array}{l}\text { РД 52.24.407-95 / } \\
\text { GD 52.24.407-95 }\end{array}$ & от 10 до 250 & $1,4+0,030 \mathrm{Cl}^{-}$ \\
\hline $\begin{array}{l}\text { РД 52.24.407-2006/ } \\
\text { GD 52.24.407-2006 }\end{array}$ & от 10 до 250 & $1,4+0,030 \mathrm{Cl}^{-}$ \\
\hline $\begin{array}{l}\text { РД 52.24.407- } 2017 / \\
\text { GD 52.24.407- } 2017\end{array}$ & от 10 до 1000 & $1,4+0,030 \mathrm{Cl}^{-}$ \\
\hline
\end{tabular}

\section{РЕЗУЛЬТАТЫ И ОБСУЖДЕНИЕ}

Особенность гидрохимического режима реки Волги зависит от нескольких причин - 1) 3,5-тысячекилометровая протяженность; 2) транзит русла пересекает несколько географических зон; 3) химический состав вод реки не соответствует химическому составу вод боковых притоков; 4) основным регулятором водного стока Волги является Куйбышевское водохранилище.

Концентрация хлоридов в воде Куйбышевского водохранилища формируется главным образом под влиянием водохранилищ, расположенных выше по течению. Влияние боковых притоков (Свияга, Вятка, Черемшан), расположенных на местной водосборной территории Куйбышевского водохранилища, на содержание в воде хло- ридов незначительно, так как объемы поступающей от них воды малы.

За период 2001-2018 годов средняя годовая концентрация хлоридов в створе Жигулевского гидроузла составила $27 \pm 2,2 \mathrm{мг} /$ дм$^{3}$, наибольшая

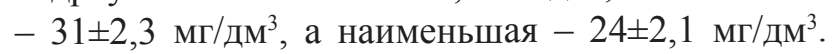
Межгодовые изменения концентрации хлоридов и расходов воды взаимосвязаны. За этот же период средний годовой расход воды составил 7,7 тыс. $\mathrm{m}^{3} / \mathrm{c}$, наибольший $-9,0$ тыс. $\mathrm{m}^{3} / \mathrm{c}$, а наименьший $-6,2$ тыс. м $3 /$ c. К многоводным годам следует отнести 2004, 2005, 2007 и 2013, а к маловодным - 2006, 2010, 2011 и 2015. В маловодные годы концентрация хлоридов увеличивалась, а в многоводные годы - уменьшалась (рис. 2). 


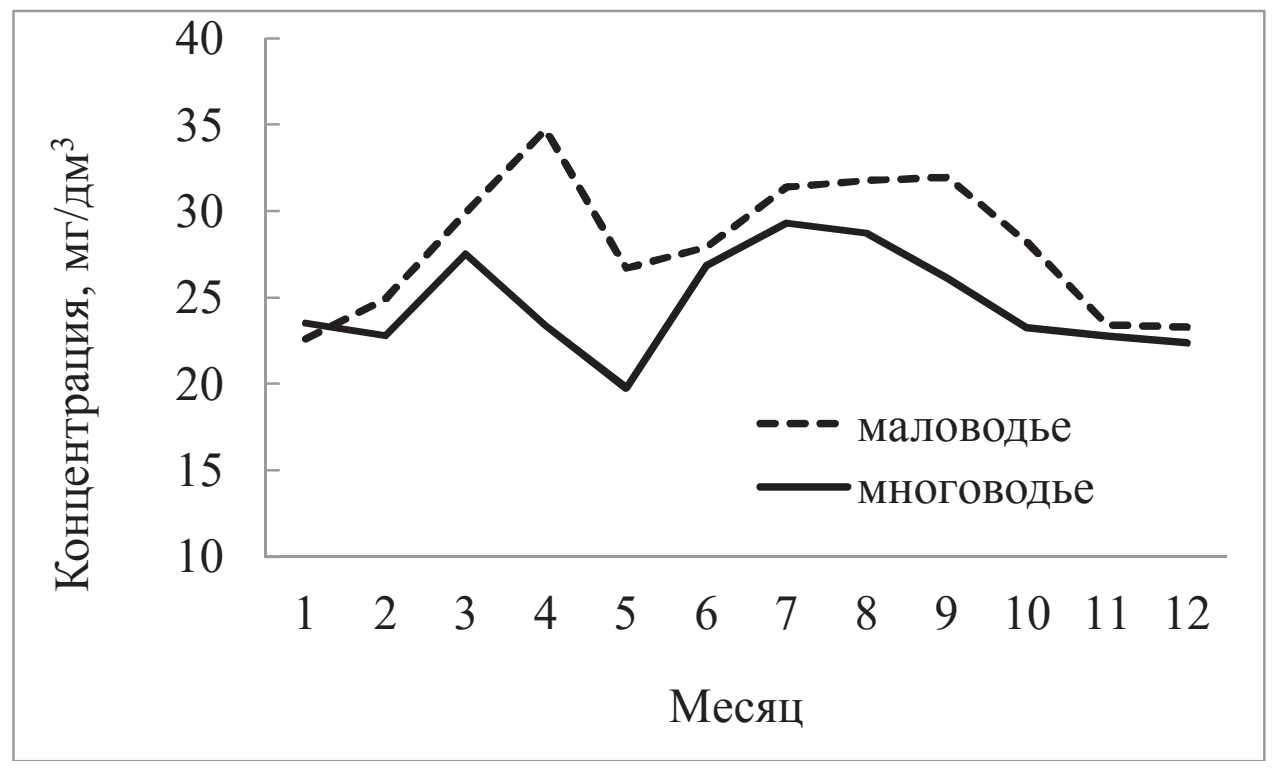

Puc. 2. Влияние водности на концентрацию хлоридов в воде

[Fig. 2. Influence of water content on the concentration of chlorides in water]

Сезонные изменения расходов воды были намного больше межгодовых колебаний. Средние месячные расходы воды $(\mathrm{Q})$ изменялись весьма существенно от 5,3 тыс. $\mathrm{m}^{3} / \mathrm{c}$ в октябре до 18,3 тыс. м ${ }^{3} /$ с в мае (табл. 2). Максимальные среднемесячные расходы воды $\left(\mathrm{Q}_{\max }\right)$ изменялись в пределах от 6,5 тыс. м ${ }^{3} / \mathrm{c}$ в октябре до 26,1 тыс. м³/с в мае. Минимальные расходы воды $\left(\mathrm{Q}_{\min }\right)$ изменялись от 4,1 тыс. м $^{3} /$ с в ноябре до 11,1 тыс. м ${ }^{3}$ с в мае.

Принято выделять три гидрологических сезона: зимнюю межень (декабрь-март), весеннее половодье (апрель-июнь) и летне-осеннюю межень (июль-ноябрь). Самый короткий - это период весеннего половодья, когда наблюдалась наибольшая амплитуда колебаний расходов воды и составляла 8,7-18,3 тыс. $\mathrm{m}^{3} / \mathrm{c}$.

Таблица 2

Сезонное распределение расходов воды, тыс. ${ }^{3} / \mathrm{c}$

[Table 2. . Seasonal distribution of water flow rates, thousand $\mathrm{m}^{3} / \mathrm{s}$ ]

\begin{tabular}{|c|c|c|c|c|c|c|c|c|c|c|c|c|}
\hline \multirow{2}{*}{$\begin{array}{c}\text { Расход воды / } \\
\text { Discharge }\end{array}$} & \multicolumn{12}{|c|}{ Месяц / Month } \\
\hline & 1 & 2 & 3 & 4 & 5 & 6 & 7 & 8 & 9 & 10 & 11 & 12 \\
\hline Q & 5,9 & 6,2 & 5,9 & 11,8 & 18,3 & 8,7 & 6,5 & 5,8 & 5,6 & 5,3 & 6,2 & 6,3 \\
\hline $\mathrm{Q}_{\max }$ & 7,4 & 9,0 & 8,7 & 18,6 & 26,1 & 13,8 & 14,1 & 8,1 & 6,6 & 6,5 & 12,4 & 8,8 \\
\hline $\mathrm{Q}_{\min }$ & 4,5 & 4,9 & 4,2 & 5,1 & 11,1 & 5,0 & 4,8 & 2,1 & 4,4 & 4,2 & 4,1 & 4,5 \\
\hline
\end{tabular}

Устойчивые расходы воды отличались в период зимней межени и равнялись 5,9-6,3 тыс. м²/c. Период летне-осенней межени - самый продолжительный. Расходы воды стабильны и составляли 5,3-6,5 тыс. $\mathrm{M}^{3} / \mathrm{c}$.
В сезонном разрезе средняя месячная концентрация хлоридов $\left(\mathrm{Cl}^{-}\right)$колебалась в пределах от $22,8 \pm 2,1$ в декабре до $30,6 \pm 2,3$ мг/дм³ в апреле перед началом весеннего половодья (табл. 3).

Сезонные изменения концентрации хлоридов, мг/дм³

Таблица 3

[Table 3. Seasonal changes in chloride concentration, $\mathrm{mg} / \mathrm{dm}^{3}$ ]

\begin{tabular}{|c|c|c|c|c|c|c|c|c|c|c|c|c|}
\hline \multirow{2}{*}{$\begin{array}{l}\text { Хлориды / } \\
\text { Chlorides }\end{array}$} & \multicolumn{12}{|c|}{ Месяц / Month } \\
\hline & 1 & 2 & 3 & 4 & 5 & 6 & 7 & 8 & 9 & 10 & 11 & 12 \\
\hline $\mathrm{Cl}^{-}$ & 24,1 & 26,4 & 28,8 & 30,6 & 24,5 & 28,7 & 30,2 & 29,9 & 28,3 & 25,8 & 24,3 & 22,8 \\
\hline$\left(\mathrm{Cl}^{-}\right)_{\max }$ & 27,9 & 39,1 & 35,6 & 41,3 & 34,1 & 41,0 & 39,3 & 35,0 & 36,7 & 29,8 & 29,3 & 26,9 \\
\hline$\left(\mathrm{Cl}^{-}\right)_{\min }$ & 20,0 & 21,7 & 20,4 & 22,0 & 14,0 & 19,3 & 21,8 & 24,0 & 22,9 & 21,8 & 20,8 & 18,6 \\
\hline
\end{tabular}


За весь период наблюдений внутригодовая амплитуда среднемесячных концентраций хлоридов составила 14-42 мг/дм³. Столь значительные сезонные изменения обусловлены колебанием водности реки. В многоводные годы в период весеннего половодья концентрация хлоридов резко снижалась, а в маловодные годы - увеличивалась в период летней и зимней межени.
Максимальные концентрации $\left(\mathrm{Cl}^{-}\right)_{\max }$ изменялись от $26,9 \pm 2,2$ мг/дм ${ }^{3}$ в декабре до 41,3 $\pm 2,6$ мг/дм ${ }^{3}$ в апреле. Минимальные концентрации $\left(\mathrm{Cl}^{-}\right)_{\min }$ варьировали от $14,0 \pm 1,8$ мг/дм ${ }^{3}$ в мае до $24,0 \pm 2,1$ $\mathrm{Mг} /$ дм $^{3}$ в августе. Закономерности сезонной изменчивости концентрации хлоридных ионов представлены на рисунке 3.

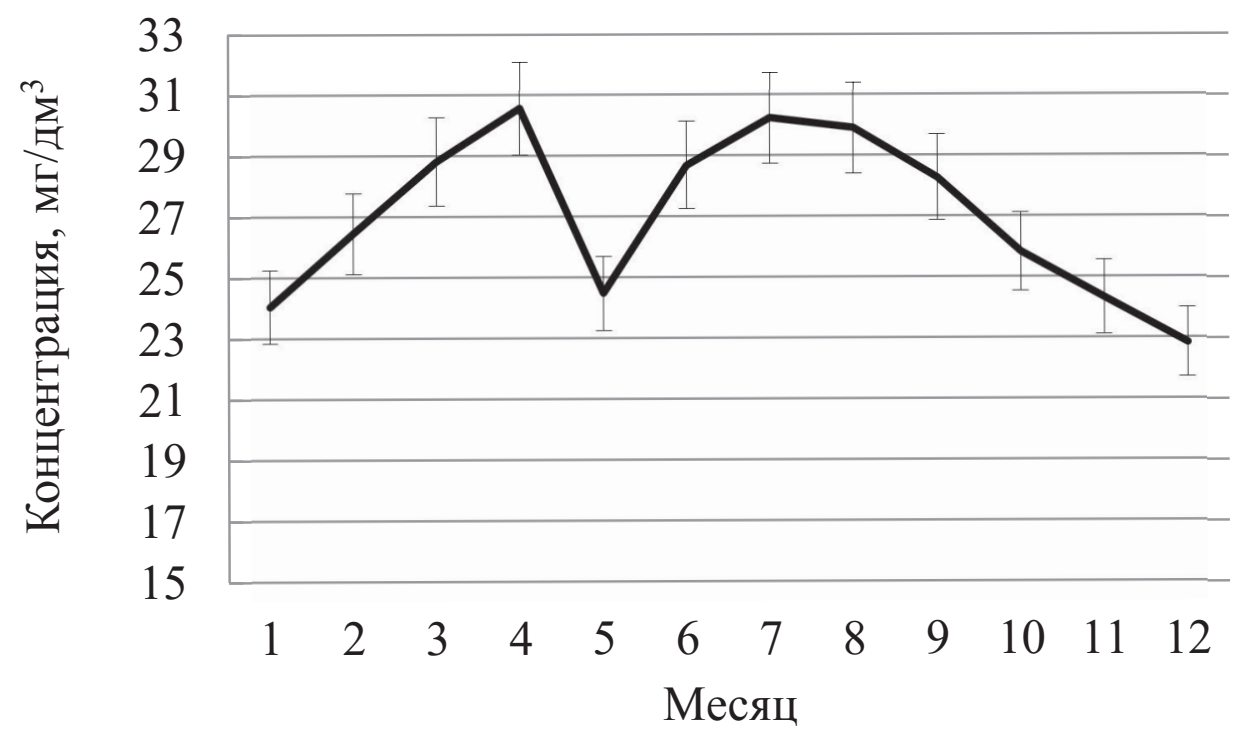

Puc. 3. Сезонные изменения концентрации хлоридов $\left(\mathrm{Cl}^{-}\right)$ ( $\mathrm{T}, \perp$ - вертикальные планки погрешностей)

[Fig. 2. Influence of water content on the concentration of chlorides in water $(\mathrm{T}, \perp-$ vertical error bars $)$ ]

Сезонная изменчивость концентрации хлоридов обусловлена притоком различных водных масс в результате взаимодействия поверхностной и подземной составляющих водного стока. В период зимней межени концентрация хлоридов увеличивалась за счет возрастающей роли подземного стока. В период весеннего половодья концентрация хлоридов резко снижалась, достигая минимальных значений в мае в период прохождения талых вод. Затем их концентрация постепенно увеличивалась до максимальных значений в июле. Усвоение хлоридов водными организмами отсутствует, поэтому в период массового развития водорослей концентрация ионов $\left(\mathrm{Cl}^{-}\right)$увеличивалась, и только осенью наблюдалось постепенное уменьшение концентрации. В рамках конкретного года амплитуда колебаний зависела от объема весеннего половодья. Чем больше объем половодья, тем больше амплитуда сезонных колебаний концентрации хлоридов в воде.

\section{ЗАКЛЮЧЕНИЕ}

Концентрация хлоридных ионов в воде реки Волга характеризуется незначительными межгодовыми изменениями. За период 2001-2018 годов средняя годовая концентрация составила 27 мг/дм³, наибольшая - 31 мг/дм³ , а наименьшая - 24 мг/дм ${ }^{3}$.
Абсолютные значения концентрации хлоридов в замыкающем створе Куйбышевского водохранилища (Жигулевский гидроузел) сформированы в результате смешения вод, поступающих из Чебоксарского и Нижнекамского водохранилищ. Межгодовые изменения концентрации связаны с водностью реки и обусловлены климатическими колебаниями.

Сезонное варьирование концентрации хлоридов более значительны, чем межгодовые изменения. В сезонном разрезе средняя месячная концентрация колебалась в пределах от 22,8 до 30,6 мг/дм³. Максимальные концентрации изменялись от 26,9 до 41,3 мг/дм ${ }^{3}$, минимальные $\left(\mathrm{Cl}^{-}\right)_{\min }$ - от 14,0 до 24,0 мг/дм³. Внутригодовые изменения концентрации в основном зависят от соотношения поверхностных и подземных вод, а также от регулирования водного стока на Жигулевском гидроузле.

При оценке качества воды и определении пространственной неоднородности концентрации хлоридных ионов необходимо учитывать закономерности их сезонной изменчивости. Актуальность проблемы изучения химизма волжской воды еще более возрастает в связи с реализацией государственной программы «Оздоровление Волги». 


\section{СПИСОК ЛИТЕРАТУРЫ}

1. Беспалова К.В., Селезнев В.А., Селезнева А.В. Качество вод волжских водохранилищ в условиях глобального потепления климата // Ресурсосбережение $и$ экологическое развитие территорий, 2017, с. 126-129.

2. Беспалова К. В., Селезнева А.В., Селезнев В.А. Сезонная изменчивость концентрации минерального фосфора в воде Саратовского водохранилища // Тезисы докладов Всероссийской конференичи «Волга и её жизнь», 2018, с. 8.

3. Воды России (состояние, использование, охрана) 1995. Екатеринбург: РосНИИВХ, 1996. 103 с.

4. Дебольский В.К., Григорьева И.Л., Комиссаров А.Б. Изменение химического состава воды в Волге от истока к устью в летнюю межень 2009 года // Охрана окружающей среды и природопользование, 2011, № 3, с. 68-73.

5. Дебольский В.К., Григорьева И.Л., Комиссаров А.Б., Корчагина Я.П., Хрусталева Л.И., Чекмарева Е.А. Современная гидрохимическая характеристика реки Волга и ее водохранилищ // Вода: химия и экология, 2010, № 11, с. 2-12.

6. Качество поверхностных вод Российской Федерации. Ежегодник. 2019. Ростов-на-Дону: Росгидромет, 2020. $578 \mathrm{c.}$

7. Никаноров А. М. Гидрохимия. СПб.: Гидрометеоиздат, 2001. 447 c.

8. Никаноров А.М., Брызгало В.А., Косменко Л.С. Роль речного притока растворенных химических веществ в антропогенной трансформации состояния водной среды устьевой области реки Волга // Вода: $x u$ мия и экология, 2010, № 7, с. 6-12.

9. О состоянии и использовании водных ресурсов Российской Федерации в 2018 году: Государственный доклад. М.: НИА - Природа, 2019. 290 с.
10. Селезнева А. В. От мониторинга к нормированию антропогенной нагрузки на водные объекты. Самара: СамНЦ РАН, 2007. 107 с.

11. Селезнева А. В., Беспалова К. В., Селезнев В. А. Оценка сезонной изменчивости качества воды в поверхностном источнике питьевого водоснабжения // Градостроительство и архитектура, 2018, т. 8, № 2 (31), c. 20-26. DOI:10.17673/Vestnik.2018.02.4.

12. Татарников В. О., Гаврилова Е. В. Многолетняя динамика и прогноз стока тяжелых металлов на Нижней Волге в связи с реализацией государственной программы «Оздоровление Волги» // Вестник Воронежского государственного университета. Серия: География. Геоэкология, 2019, № 1, с. 85-91. DOI: https://doi. org/10.17308/geo.2019.1/2288

13. Торгашкова О.Н., Воловик Н.С. Комплексная оценка степени загрязнения водной среды реки Волги // Известия Саратовского университета. Серия: Химия. Биология. Экология, 2012, т. 12, вып. 4, с. 96-102.

14. Шашуловская Е.А., Мосияш С.А., Орлов А.А., Фокина Л.Н. Многолетние изменения качества воды участков Нижней Волги, различающихся по гидрологическому режиму // Известия Самарского научного центра Российской академии наук, 2016, т. 18, № 5 (2), с. 382-386.

15. Seleznev V.A., Bespalova K.V., Selezneva A.V. Seasonal Variability of Phosphate Content in the Volga Water Under Conditions of Anthropogenic Eutrophication of Reservoirs // Journal of Water Chemistry and Technology, 2018, т. 40, № 5, pp. 307-311. DOI:10.3103/ s1063455X18050107

Конфликт интересов: Авторы декларируют отсутствие явных и потенциальных конфликтов интересов, связанных с публикацией настоящей статьи.

Поступила в редакциию 11.06.2021

Принята к публикаџии 23.11.2021

DOI: https://doi.org/10.17308/geo.2021.4/3748

\title{
Chloride Ion Content in the Water of the Volga River
}

\author{
V.A. Seleznev ${ }^{凶}$, A. V. Selezneva \\ Samara Federal Research Centre of the Russian Academy of Sciences, \\ Institute of Ecology of the Volga Basin of the Russian Academy of Sciences, Russian Federation \\ (10, Komzin Str., Samara region, Togliatti, 445003)
}

\begin{abstract}
The purpose of the research is to determine the patterns of seasonal variability of chloride ions content in the Volga River water and to quantify the amplitude of inter- and intra-annual variations taking into account years of different water availability.
\end{abstract}

(C) Seleznev V.A., Selezneva A. V., 2021

\Vladimir A. Seleznev, e-mail: seleznev53@mail.ru

(c) (i) The content is available under Creative Commons Attribution 4.0 License.

Вестник ВГУ, Серия: География. Геоэкология, 2021, № 4, 34-41 
Materials and methods. Systematic hydrochemical observations were carried out on the Volga River during the period 2001-2018. The stationary observation site was located on the left bank of the river, $2.5 \mathrm{~km}$ downstream of the Zhigulevsky hydrosystem (the closing section of the Kuibyshev reservoir). Water samples were taken from the concrete wall with Molchanov GR-18 batometer from the surface horizon. The number of samples taken is 216. Mass concentration of chloride ions (Cl-) was determined in accordance with the applicable Roshydromet guidelines. Statistical analysis of water discharge data and concentration of chloride ions was carried out using Statistica software.

Results and discussion. The average concentration of chloride ions during the 18-year observation period was $27.0 \pm 2.2 \mathrm{mg} / \mathrm{dm} 3$. The highest mean annual chloride concentration reached $31.0 \pm 2.3 \mathrm{mg} / \mathrm{dm} 3$ and the lowest $24.2 \pm 2.1 \mathrm{mg} / \mathrm{dm} 3$. Chloride content was characterized by a pronounced seasonal variability. During the winter low-water period there was a gradual increase in chloride concentration. The maximum was observed in April, before the spring flood. During the spring flood, chloride concentrations decreased sharply, reaching their lowest values in May at the peak of the spring flood. Their concentration gradually increased during the summer and decreased during the autumn. The seasonal amplitude of chloride concentrations varied from $14.0 \pm$ $1.8 \mathrm{mg} / \mathrm{dm} 3$ to $41.3 \pm 2.6 \mathrm{mg} / \mathrm{dm} 3$. In years of varying water availability, the amplitude of seasonal fluctuations can increase or decrease. During the spring flood periods of high-water years, chloride concentrations decreased sharply, while during low-water years they increased significantly. In general, during high-water years the chloride concentration decreased, while during low-water years it increased due to a change in the ratio of surface and groundwater components of water flow formation.

Conclusions. When assessing water quality and determining the spatial heterogeneity of chloride ion concentrations, patterns of their seasonal variability must be taken into account.

Key words: Volga River, Zhigulevsky hydrosystem, chloride ions, seasonal variability, impact of water availability.

For citation: Seleznev V.A., Selezneva A. V. Chloride Ion Content in the Water of the Volga River. Vestnik Voronezskogo gosudarstvennogo universiteta. Seria: Geografia. Geoekologia, 2021, no. 4, pp. 34-41. (In Russ.) DOI: https://doi.org/10.17308/geo.2021.4/3748

\section{REFERENCES}

1. Bespalova K.V., Seleznev V.A., Selezneva A.V. Kachestvo vod volzhskikh vodokhranilishch v usloviyakh global'nogo potepleniya klimata [The water quality of the Volga reservoirs in the context of global climate warming]. Resursosberezheniye i ekologicheskoye razvitiye territoriy, 2017, pp. 126-129. (In Russ.)

2. Bespalova K.V., Selezneva A.V., Seleznev V.A. Sezonnaya izmenchivost' kontsentratsii mineral'nogo fosfora v vode Saratovskogo vodokhranilishcha [Seasonal variability of the concentration of mineral phosphorus in the water of the Saratov reservoir]. Tezisy dokladov Vserossiyskoy konferentsii "Volga $i$ ee zhizn'», 2018, pp. 8. (In Russ.)

3. Vody Rossii (sostoyaniye, ispol'zovaniye, okhrana) 1995 [Waters of Russia (state, use, protection) 1995]. Ekaterinburg: RosNIIVKH, 1996. 103 p. (In Russ.)

4. Debol'skiy V. K., Grigor'yeva I. L., Komissarov A. B. Izmeneniye khimicheskogo sostava vody v Volge ot istoka k ust'yu v letnyuyu mezhen' 2009 goda [Changes in the chemical composition of water in the Volga from source to mouth in the summer low-water period of 2009]. Okhrana okruzhayushchey sredy i prirodopol'zovaniye, 2011, no. 3, pp. 68-73. (In Russ.)

5. Debol'skiy V.K., Grigor'yeva I.L., Komissarov A. B., Korchagina YA.P., Khrustaleva L. I., Chekmareva Ye.A. Sovremennaya gidrokhimicheskaya kharakteristika reki Volga i yeye vodokhranilishch [Modern hydrochemical characteristics of the Volga River and its reservoirs]. Voda: khimiya i ekologiya, 2010, no.11, pp. 2-12. (In Russ.)

6. Kachestvo poverkhnostnykh vod Rossiyskoy Federatsii. Yezhegodnik. 2019 [Surface water quality of the Russian Federation. Yearbook. 2019]. Rostov-on-Don: Rosgidromet, 2020. 578 p. (In Russ.)

7. Nikanorov A. M. Gidrokhimiya [Hydrochemistry]. Saint-Peterburg: Gidrometeoizdat, 2001. 447 p. (In Russ.)

8. Nikanorov A. M., Bryzgalo V.A., Kosmenko L.S. Rol' rechnogo pritoka rastvorennykh khimicheskikh veshchestv $\mathrm{v}$ antropogennoy transformatsii sostoyaniya vodnoy sredy ust'yevoy oblasti reki Volga [The role of the river inflow of dissolved chemicals in the anthropogenic transformation of the state of the aquatic environment in the mouth area of the Volga river]. Voda: khimiya i ekologiya, 2010, no. 7, pp. 6-12. (In Russ.)

9. O sostoyanii i ispol'zovanii vodnykh resursov Rossiyskoy Federatsii v 2018 godu: Gosudarstvennyy doklad [On the state and use of water resources of the Russian Federation in 2018: State report]. Moscow: NIA - Priroda, 2019. 290 p. (In Russ.)

10. Selezneva A. V. Ot monitoringa $k$ normirovaniyu antropogennoy nagruzki na vodnyye ob"yekty [From monitoring to regulation of anthropogenic load on water bodies]. Samara: SamNTS RAN, 2007. 107 p. (In Russ.)

11. Selezneva A. V., Bespalova K. V., Seleznev V.A. Otsenka sezonnoy izmenchivosti kachestva vody v poverkhnostnom istochnike pit'yevogo vodosnabzheniya [As- 
sessment of seasonal variability of water quality in a surface source of drinking water supply]. Gradostroitel'stvo $i$ arkhitektura, 2018, v. 8, no. 2 (31), pp. 20-26. (In Russ.) DOI:10.17673/Vestnik.2018.02.4

12. Tatarnikov V.O., Gavrilova E.V. Mnogoletnyaya dinamika i prognoz stoka tyazhelykh metallov na Nizhney Volge $\mathrm{v}$ svyazi s realizatsiey gosudarstvennoy programmy «Ozdorovlenie Volgi» [Long-term dynamics and forecast of heavy metals runoff on the Lower Volga in connection with the implementation of the state program "Volga Recovery"]. Vestnik Voronezhskogo gosudarstvennogo universiteta. Seria: Geografia. Geoekologia, 2019, no.1, pp. 85-91. (In Russ.) DOI: https://doi.org/10.17308/ geo.2019.1/2288

13. Torgashkova O.N., Volovik N.S. Kompleksnaya otsenka stepeni zagryazneniya vodnoy sredy reki Volgi [Comprehensive assessment of the degree of pollution of the water environment of the Volga River]. Izvestiva Saratovskogo universiteta. Seriya: Khimiya. Biologiya. Ekologiya, 2012, vol. 12, vol. 4, pp. 96-102. (In Russ.)

Селезнев Владимир Анатольевич

профессор, доктор технических наук, кандидат географических наук, главный научный сотрудник лаборатории мониторинга водных объектов Самарского федерального исследовательского центра РАН, Института экологии Волжского бассейна Российской академии наук, Самарская обл., г. Тольятти, Российская Федерация, ORCID: 0000-0002-0321-7614, e-mail: seleznev53@, mail.ru

Селезнева Александра Васильевна

кандидат технических наук, старший научный сотрудник лаборатории мониторинга водных объектов Самарского федерального исследовательского центра РАН, Института экологии Волжского бассейна Российской академии наук, Самарская обл., г. Тольятти, Российская Федерация, ORCID: 0000-0002-9386-999X, e-mail: alek.selezneva@mail.ru
14. Shashulovskaya Ye.A., Mosiyash S.A., Orlov A.A., Fokina L. N. Mnogoletniye izmeneniya kachestva vody uchastkov Nizhney Volgi, razlichayushchikhsya po gidrologicheskomu rezhimu[Hydrochemical Dictionary]. Izvestiya Samarskogo nauchnogo tsentra Rossiyskoy akademii nauk, 2016, vol.18, no. 5(2), pp. 382-386. (In Russ.)

15. Seleznev V.A., Bespalova K. V., Selezneva A.V. Seasonal Variability of Phosphate Content in the Volga Water Under Conditions of Anthropogenic Eutrophication of Reservoirs. Journal of Water Chemistry and Technology, 2018, vol. 40, no. 5, pp. 307-311. DOI:10.3103/ s1063455X18050107.

Conflict of interests: The authors declare no information of obvious and potential conflicts of interest related to the publication of this article.

Received: 11.06.2021

Accepted: 23.11.2021

Vladimir A. Seleznev

Professor, Dr (Tech.) Sci., Candidate of Geographical Sciences, Chief Researcher of the Laboratory for Monitoring Water Bodies of the Samara Federal Research Center of the Russian Academy of Sciences, Institute of Ecology of the Volga Basin of the Russian Academy of Sciences, Samara Region, Togliatti, Russian Federation, ORCID: 0000-0002-0321-7614, e-mail: seleznev53@mail.ru

Alexandra V. Selezneva

Cand. (Tech.) Sci., Senior Researcher of the Laboratory for Monitoring Water Bodies of the Samara Federal Research Center of the Russian Academy of Sciences, Institute of Ecology of the Volga Basin of the Russian Academy of Sciences, Samara Region, Togliatti, Russian Federation, ORCID: 0000-0002-9386-999X, e-mail: alek.selezneva@ mail.ru. 